\title{
8 Food Webs in the Ocean: Who Eats Whom and How Much?
}

\author{
Andrew W. Trites \\ Marine Mammal Research Unit, Fisheries Centre, University of British Columbia, \\ Vancouver, Canada
}

\begin{abstract}
Over 100 food webs have been published for marine ecosystems to describe the transfer of food energy from its source in plants, through herbivores, to carnivores and higher order predators. The webs suggest that the lengths of the chains that form food webs are typically short (3-4 links), and that ecosystems with long food chains may be less stable than those with shorter food chains.

Stomach contents have been the primary means for determining what marine organisms eat. More recently developed techniques include faecal analysis and fatty acid signatures from blood or fat samples. Consumption has been estimated from the volume of food found in stomachs, from the feeding rates of captive individuals and from bio-energetic modelling. Consumption of marine organisms, expressed as a percentage of an individual's body weight per day, ranges from about $4-15 \%$ for zooplankton, to $1-4 \%$ for cephalopods, $1-2 \%$ for fish, 3-5\% for marine mammals and $15-20 \%$ for sea birds. Immature age classes consume about twice as much (per unit of body weight) as do mature individuals. Furthermore, consumption is not constant throughout the year, but varies with seasonal periods of growth and reproduction. Most groups of species consume 3-10 times more than they produce, and export or pass up the food web about $70-95 \%$ of their production. Marine organisms tend to be larger at successive trophic levels and are limited in the sizes of food they can consume. Humans are one of the few species that can prey upon almost any level of the food chain and any size of prey.

Food web analysis and estimates of consumption are essential for understanding which ecosystems can support additional species, and which may be less stable and susceptible to species loss through the synergistic effects of fishing or culling. They are also critical tools for understanding changes in ecosystem dynamics as highlighted by a case study from the eastern Bering Sea.
\end{abstract}

\section{Introduction}

The understanding of predator-prey relationships within marine food webs has increased enormously since the first simple food web was drawn for herring in the North Sea (Hardy, 1924). What were once simple qualitative depictions of the interrelationships between species are being replaced increasingly with quantitative descriptions of entire ecosystems. This in turn is allowing fisheries biologists to estimate better the amount of food consumed by various species, and to make predictions about the effects of 
fisheries on predator-prey relationships, and of the effects of food web dynamics on fisheries.

The following provides an overview of marine food webs and the amounts of food that marine organisms consume. Emphasis is placed on apparent patterns that a number of biologists have noted in comparing food webs among different ecosystems regarding ecosystem stability, food chain lengths and food web complexity. The efficiency of energy transfer between trophic levels is also discussed in the context of digestion and assimilation efficiencies of marine organisms; and the interplay between food webs and consumption is highlighted with a case study from the eastern Bering Sea.

\section{Food Webs}

A food chain delineates one possible pathway for the transfer of energy from plants to herbivores, to carnivores and top predators. Myriads of food chains within an ecosystem form a food web, which biologists typically have drawn as a series of interconnected species joined by lines showing the presence or absence of interactions (e.g. Fig. 8.1). This is the simplest depiction of who eats whom. Species may be identified individually or may be grouped into functional categories (e.g. groundfish or benthic invertebrates) based on similar life history characteristics or other traits.

A more refined depiction of food webs (energy flow food webs) highlights the trophic level of each species and the relative strength of the interactions (based on the amount of energy flowing from producers and consumers, e.g. Fig. 8.2). Here, species or groups of species are placed according to their trophic level (calculated as 1.0 plus the mean trophic level of the species that they consume), and the size of each box is relative to the biomass of the species. In general, trophic levels of functional groups tend to cluster about integer values (e.g. Fig. 8.2).

Energy flow food webs convey considerably more information about the ecosystem than do topological food web drawings.
However, both depictions of food webs (energy flow and topological) fail to convey which interactions are critical to maintaining the ecosystem in its normal state. For example, regardless of the amount of energy consumed or produced in a near-shore marine ecosystem, removing limpets would have little effect compared with removing urchins, because urchins dramatically alter the physical structure of the ecosystem by consuming kelp. Functional food webs thus differ from the other two depictions of food webs by highlighting the linkages that are most important to community structure (Paine, 1980; Huxham et al., 1995). However, functional relationships are not yet well enough understood to make this a practical means of depicting food webs.

Food webs are built by knowing which producers are eaten, and in what proportion consumers eat them. Stomach contents have been the principal source of dietary data and continue to be the main tool for identifying the numbers, sizes and types of species consumed by fish (e.g. Christensen, 1995). Seabird and marine mammal diets are determined in a similar manner (e.g. Pauly et al., 1998; Santos et al., 2001), although attempts are being made to determine diet from alternative means. Fatty acid signatures are one of the newer methods of identifying prey of whales and seals, using milk samples, blood samples and blubber biopsies (e.g. Grahl-Nielsen and Mjaavatten, 1991; Iverson et al., 1997; Kirsch et al., 1998). Seal diets are being determined more commonly now from the hard parts (bones, eye lenses and beaks) found in stomachs or faecal remains collected from sites where animals haul out and rest (e.g. Tollit et al., 1997; Kirkman et al., 2000; Cottrell and Trites, 2002). Stable isotope analysis is yet another recently developed technique for determining diet (e.g. Wada et al., 1991; Kaelher et al., 2000; Kelly, 2000).

\section{Comparative analyses}

Over the past 80 years, food web research has sought to reduce complexity and identify recurring patterns that might infer underlying mechanisms or represent constraints on 


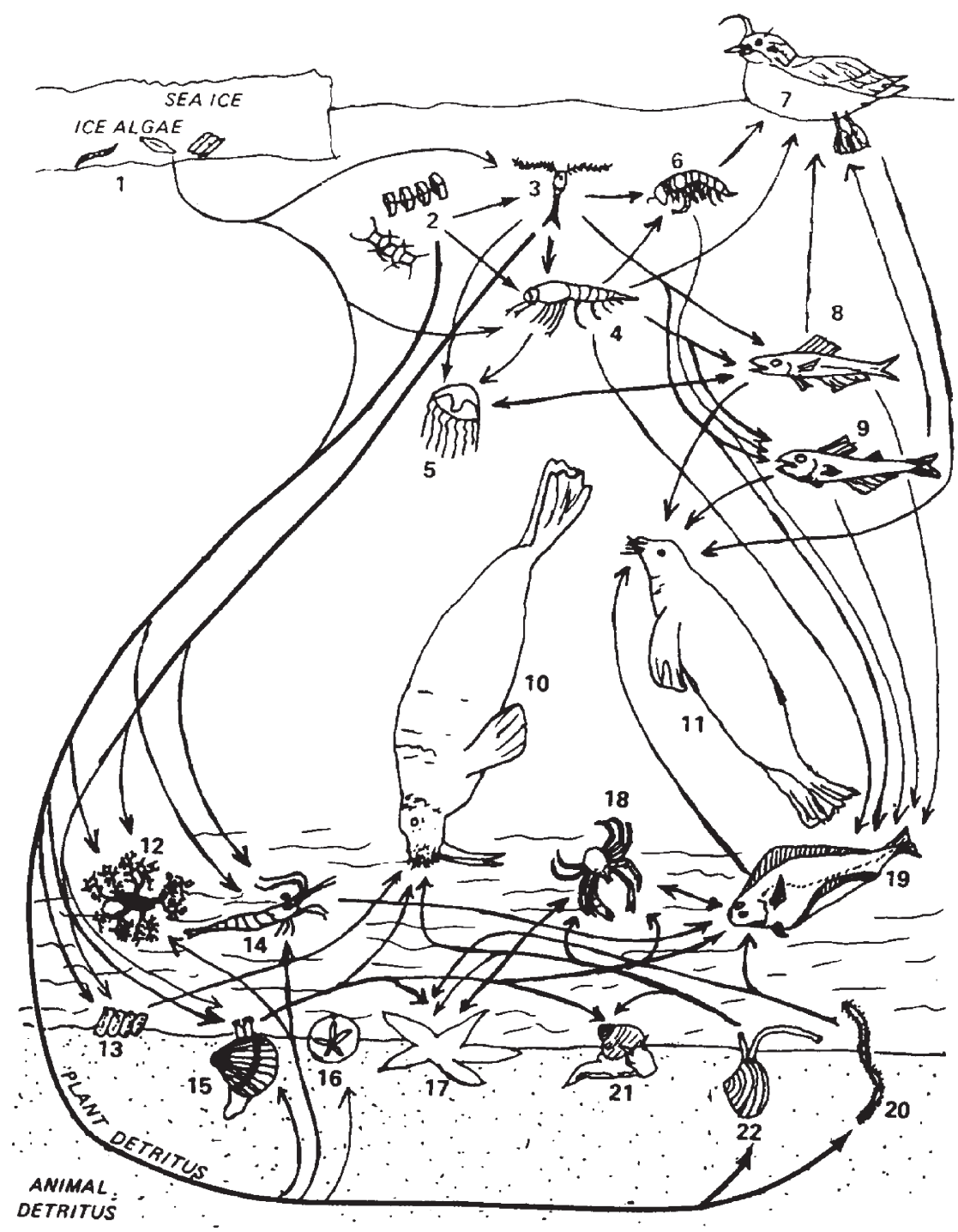

Fig. 8.1. A simplified depiction of the Bering Sea food web: (1) ice algae; (2) phytoplankton; (3) copepods; (4) mysids and euphausids; (5) medusae; (6) hyperid amphipods; (7) seabirds; $(8,9)$ pelagic fishes; (10) walrus; (11) seals; (12) basket stars; (13) ascidians; (14) shrimps; (15) filter-feeding bivalves; (16) sand dollars; (17) sea stars; (18) crabs; (19) bottom feeding fishes; (20) polychaetes; (21) predatory gastropods; (22) deposit feeding bivalves (from McConnaughey and McRoy, 1976).

ecosystem structure (e.g. Summerhayes and Elton, 1923; Elton, 1927; Cohen, 1977, 1978; Pimm, 1982, 1991; Lawton and Warren, 1988; Lawton, 1989; Cohen et al., 1990; Winemiller, 1990; Christensen and Pauly, 1993; Hall and Raffaelli, 1996; Raffaelli, 2000). Based on comparisons of food webs (mostly terrestrial ecosystems), a number of generalizations have been postulated about the sizes of organisms, the lengths of food chains and the stability of ecosystems.

Elton (1927) was among the first to remark that animals occupying successively higher trophic levels tended to be larger, and that there were upper and lower limits on the size of food that they can eat. Humans are one 


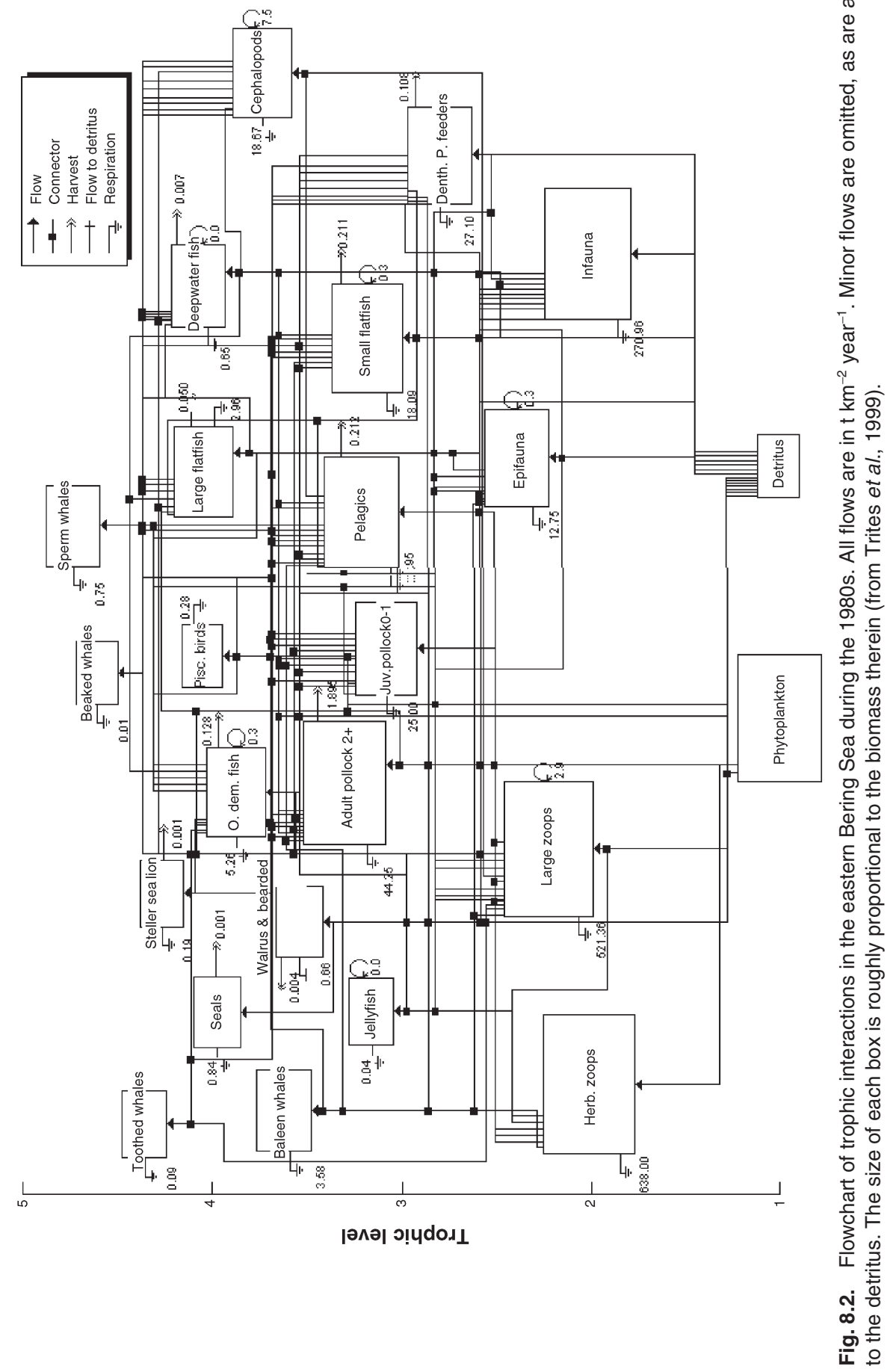


of the few species that can consume prey of any size and can feed at all trophic levels. As noted by Krebs (1996), this is one of the reasons that humans are so biologically successful. Omnivorous species are relatively rare, although there are species of fish that eat their way up the food chain as they grow. Organisms at the base of the food web tend to be more numerous than species at higher trophic levels, and are often represented as a pyramid of numbers and size (total biomass) to assess the relative distribution of biomass among trophic levels within an ecosystem (Fig. 8.3).

Overall, system biomass is proportional to primary production (Pimm, 1982), and the proportion of species occupying top, intermediate and basal trophic levels appears to be constant across food webs (Cohen, 1978). There also appears to be a relatively constant ratio of 2-3 species of prey for every predator in an ecosystem (Martinez, 1991), although numbers of species of prey consumed by each species of predator tend to increase as the size of the food web increases.

A number of biologists have noted that food chains typically are short (Elton, 1927; Hutchinson, 1959; Pimm and Lawton, 1977; Pimm, 1982; Ricklefs and Miller, 2000). However, the average number of links appears to be longer in marine ecosystems compared with freshwater communities, grasslands or wet tropical forests (Briand and Cohen, 1987; Ricklefs and Miller, 2000). Christensen and Pauly (1993) compared 41 aquatic ecosystems

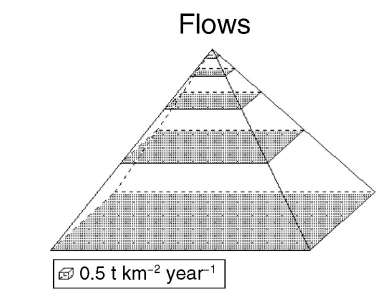

Biomass

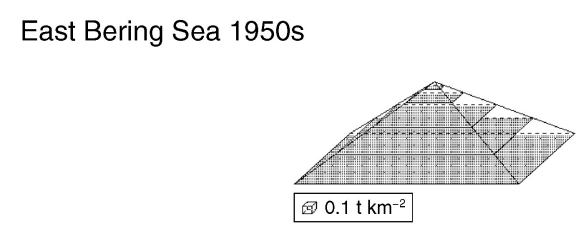

Per 1960s
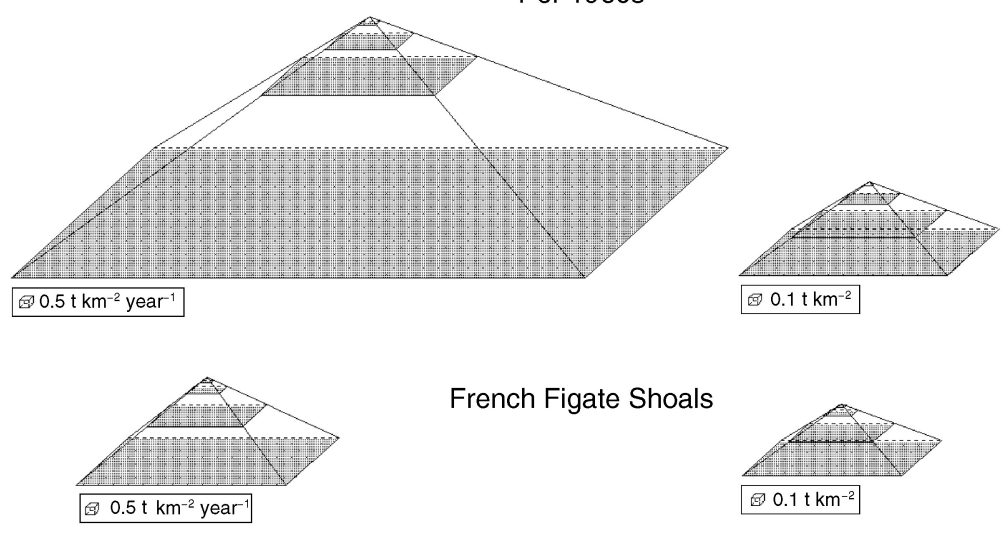

French Figate Shoals
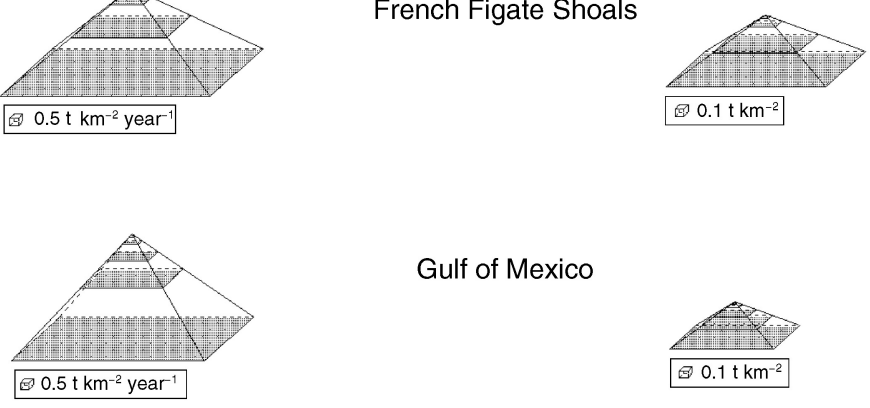

Gulf of Mexico

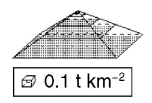

Fig. 8.3. Trophic pyramids representing the distribution of biomass and energy flow in four ecosystems. The pyramids are scaled so that the volume at each trophic level corresponds to the sum of all flows at that level. The top angles are inversely proportional to the transfer efficiency (acute angle $=$ high efficiency) (from Trites et al., 1999). 
and found average path lengths of 2-5 linkages. The longest average path lengths were in tropical estuaries (3.0-5.0), followed by tropical shelves (2.8-4.0) and oceanic upwelling areas (2.2-2.8) (Baird et al., 1991; Christensen and Pauly, 1993). Maximum chain lengths were eight in tropical shelves, seven in tropical estuaries and six in oceanic upwelling areas (Christensen and Pauly, 1993). This is supported further by a review of 75 aquatic food webs that found only three with maximum food chains longer than six (Schoener, 1989).

It appears that the average number of feeding links per species (linkage density) increases as the size of the web (i.e. number of species) increases. This implies that the number of prey that a predator will eat increases in proportion to the total number of species in that community. However, the number of links relative to all possible links (connectance) decreases as the number of groups in a food web increases (Pimm, 1982; Christensen and Pauly, 1993). Martens (1987) suggested that this might reflect an increase in ecosystem stability. However, Christensen and Pauly (1993) conclude that any interpretation of connectance is ambiguous due to the binary nature of its scoring (i.e. either a link exists or it does not, irrespective of the fraction of diet it represents).

The length of food chains may be a function of the amount of primary production at the base of the food pyramid, and the efficiency with which energy is transferred from one trophic level to the next (Hutchinson, 1959; Slobodkin, 1960). Higher rates of transfer efficiency presumably mean that more energy can be passed up the food chain to support more species. However, Pimm (1991) disputes this explanation, noting that some areas of high ocean productivity have short food chains. He argues instead that longer food chains are associated with stable environments, while shorter food chains are in less predictable environments. Species at the end of long food chains would be at risk of extinction if the abundance of species lower in the food chain fluctuated severely.

In general, it appears that food webs in variable environments have fewer linkages than webs in more constant environments
(Briand, 1983). However, it has also been shown experimentally that food chains are longer in more productive environments (Pimm and Kitching, 1987; Jenkins et al., 1992), and that population dynamics are less stable in long food chains than in short ones (Lawler and Morin, 1993). Thus it appears that the length of food chains is a function of both environmental stability and energy transfer efficiency.

\section{Limitations of food webs}

Food webs, such as those shown in Figs 8.1 and 8.2 , are collages of species interactions that sometimes conceal more than they reveal (Paine, 1988; Raffaelli, 2000). For example, some of the interactions may not occur simultaneously, or they may change over seasons or years. They also tend to be oversimplifications. Similarly, some interactions, such as parasite/pathogen-host interactions or mutualistic interactions, may be critical to community dynamics but fail to be captured by food web depictions (Cohen, 1993; Paine, 1994; Huxham et al., 1995; Hall and Raffaelli, 1996).

Food web diagrams are useful tools for conceptual understanding of ecosystems despite their shortcomings and the inadequacy of many of the food webs used in comparative analyses (see critiques by Paine, 1988; Polis, 1991; Hall and Raffaelli, 1993, 1996). With the advent of quantitative ecosystem modelling tools (e.g. Christensen and Pauly, 1992; Jørgensen, 1998), food web analysis is leading towards a better understanding of food web structure and the design of better management strategies for conservation. The structure of food webs has implications for community persistence (Pimm, 1991), and may provide insights into which systems can support additional species, and which are unstable and susceptible to species losses. This is particularly relevant to understanding the effects on food webs of culling (e.g. Yodzis, 1998), overfishing (e.g. Christensen, 1998; Hacquebord, 1999; Jackson et al., 2001) or introducing exotic species (e.g. Grosholz et al., 2000). Food web analysis may also help to 
identify which processes are critical to the ecosystem, and highlight which components need more research (Wooten, 1994).

\section{Food Consumption}

Consumption can be expressed as the total amount eaten, or as the rate (i.e. velocity) that energy is ingested. For the purpose of this review, consumption is defined as the amount of food eaten in a fixed period of time (i.e. days or years).

Organisms require energy for growth, reproduction, physical activity and maintenance of cells and organs, and must ingest sufficient calories to meet these fixed costs of living. However, organisms cannot assimilate all of the energy contained within the food they ingest due to differences in the nutrient content and digestibility of different types of prey. For example, an organism that ingests excess nitrogen in its diet will excrete it as energy in the form of nitrogen-containing organic waste. Thus, energy that is digested and absorbed (assimilated energy) is a function of digestive physiology and of the make up of the prey (e.g. proportion of bones, scales, exoskeleton, etc.). Digestibility of ingested prey may also vary by season. Generally, foods of animal origin are easier to digest than foods of plant origin, and vertebrates are easier to digest than invertebrates. Thus assimilation efficiency depends on the quality of the diet (particularly the amount of digestion-resistant structural material it contains) and varies from about 15 to $90 \%$. Non-assimilated energy - excreted in the form of waste - contributes to detritus and is consumed by species specializing in digesting recalcitrant materials. Within the context of an ecosystem, no energy is wasted energy.

Assimilated energy can be used by the organism for the synthesis of new biomass (production) through growth and reproduction, which can be consumed by organisms at higher trophic levels. The fraction of ingested food that is used for production is lowest in organisms whose costs of maintenance and activity are greatest, and highest in species with low maintenance and activity costs (e.g. $0.2-0.3 \%$ gross food conversion efficiency in mammals, $1.1-1.5 \%$ in birds, $15-30 \%$ in fish and $30-40 \%$ in cephalopods; see Table 8.1 ).

\section{Estimating energy requirements}

There are a number of ways to estimate the amount of food consumed by marine organisms. Stomach content analysis is one method of determining daily ration, but involves making a number of assumptions about frequency of feeding and seasonal changes in energy requirements (e.g. Jarre et al., 1991). Another approach is to infer feeding rates from those of captive-fed individuals, or to measure the metabolism of free-ranging individuals (e.g. via doubly labelled water) or of captive individuals (via oxygen exchange)

Table 8.1. Approximate rates of consumption, growth, efficiency and turnover for six major species groups. Q/B is the ratio of ingested energy to biomass, and is expressed as a daily and annual rate of consumption. Population growth rate is expressed as the ratio of annual production to biomass (P/B), and gross food efficiency $(P / Q)$ is the fraction of ingested gross energy that is converted into production (growth). Turnover rate is the average residency time of energy within each species group (expressed in years).

\begin{tabular}{lccccc}
\hline Species & $\begin{array}{c}\text { Consumption } \\
\text { Q/B day }\end{array}$ & $\begin{array}{c}\text { Consumption } \\
\text { Q/B year }\end{array}$ & $\begin{array}{c}\text { Growth rate } \\
\text { P/B year }\end{array}$ & $\begin{array}{c}\text { Gross efficiency } \\
\text { P/Q }\end{array}$ & $\begin{array}{c}\text { Turnover rate } \\
\text { B/P years }\end{array}$ \\
\hline Sea birds & $0.15-0.20$ & $55-73$ & 0.80 & $0.011-0.015$ & 1.25 \\
Mammals & $0.03-0.05$ & $11-18$ & $0.02-0.06$ & $0.002-0.003$ & $17.00-50.00$ \\
Fish & $0.01-0.02$ & $3-8$ & $0.60-2.50$ & $0.150-0.300$ & $0.40-1.70$ \\
Crabs and shrimp & $0.02-0.05$ & $8-20$ & $1.50-3.00$ & $0.150-0.200$ & $0.30-0.70$ \\
Squid & $0.01-0.04$ & $4-15$ & $1.50-4.50$ & $0.300-0.400$ & $0.20-0.70$ \\
Zooplankton & $0.04-0.15$ & $15-55$ & $2.50-6.50$ & $0.120-0.170$ & $0.15-0.40$ \\
\hline
\end{tabular}

Source: based on Christensen (1995) and Trites et al. (1999). 
(e.g. Winberg, 1956; Mann, 1978; Innes et al., 1987). An alternative, but practically impossible method in aquatic systems, is to derive consumption from estimates of biomass missing from lower trophic levels. A fifth approach is modelling.

Models typically synthesize information (either measured or assumed from related species) about the costs of basal metabolism, activity, growth, reproduction, excreted waste and assimilation efficiencies - and range from simple to detailed accountings. The simplest approach estimates food consumption as a function of food conversion efficiency and mean individual weight (e.g. Kendeigh et al., 1977; Croxall et al., 1984; Pauly, 1986, 1989; Innes et al., 1987; Christensen, 1995; Guinet et al., 1996; Trites et al., 1997; Palomares and Pauly, 1998). A more detailed approach but more difficult to parameterize - calculates the costs of Respiration (the energy used for work that is degraded to heat), Production (energy deposited into tissue growth, fat storage, eggs, sperm, etc.), and Faeces and Urine (energy excreted from the body) such that

\section{Consumption $=$ Faeces + Urine + Respiration + Production}

for an organism that is in energy balance (e.g. Klekowski and Duncan, 1975; Stenson et al., 1997; Winship et al., 2002). Multiplying the mean individual consumption by population density yields an estimate of total consumption by a group of organisms.

Energy requirements are a function of body size and assimilation efficiency of different diets. Metabolic needs for maintenance are a function of body weight raised to the power of $0.70-0.75$, and are lower per unit of body mass for larger species or individuals compared with smaller ones (Kleiber, 1975). However, young animals have significantly higher rates of consumption compared with mature individuals due to the high energetic cost of growth. Thus, estimating consumption requires estimates of animal density, assimilation efficiency and performance (growth, activity and maintenance), which in turn depend on animal physiology, and on the digestibility and other nutritional properties of the food.

On average, consumption of marine organisms (expressed as a percentage of an individual's body weight per day) ranges from about $4-15 \%$ for zooplankton, to $1-4 \%$ for cephalopods, $1-2 \%$ for fish, $3-5 \%$ for marine mammals, and $15-20 \%$ for sea birds (calculated from Q/B ratios in Christensen, 1995; Trites et al., 1999, Table 8.1). However, consumption is not constant throughout the year, but varies with seasonal changes in growth and reproduction (e.g. Paul et al., 1993, 1998; Winship et al., 2002). Some organisms, such as baleen whales, may only feed for 6 months of the year, while other may fast for periods of days or weeks (Pauly et al., 1998). Finally, the nutritional quality and energy content of prey may also change seasonally (e.g. Paul et al., 1993, 1998).

\section{Transfer efficiencies and turnover times}

The number of trophic levels in marine ecosystems averages between four and six, and appears to increase from coastal systems to reefs and shelves, and decline for upwelling systems (Christensen and Pauly, 1993). The fraction of energy that enters one trophic level and passes on to the next higher trophic level (transfer efficiency) typically is low (Lindeman, 1942), and decreases with higher trophic levels due to increased respiration (Burns, 1989).

As a general rule of thumb, gross food conversion efficiency decreases at higher trophic levels (Table 8.1), and transfer efficiency (assimilation or gross production at level $n$ divided by that at level $n-1$ ) remains constant between trophic levels, at about 10\% (Kozlovsky, 1968; Pauly and Christensen, 1995). A comparison of aquatic ecosystems suggests ecological efficiencies of about $10 \%$ for herbivores and detritivores, $11 \%$ for the next trophic level, and lower efficiencies of $7.5-9.0 \%$ at higher levels (Christensen and Pauly, 1993). Most energy held within a trophic level is dissipated before organisms feeding at the next higher trophic level can consume it. Ultimately, the amount of energy reaching each trophic level depends on the net primary production at the base of the food chain and on the conversion efficiencies. Thus, high fish catches are associated with high 
primary productivity and with fishing at lower trophic levels (Christensen, 1996).

The turnover or residency time of energy at each trophic level can be calculated by dividing the biomass (total stored energy) by net productivity (the rate at which energy is converted into biomass). This effectively is the time it takes energy to flow through the ecosystem (Ricklefs and Miller, 2000). Average turnover times in marine ecosystems range from about 6 days for phytoplankton to 3 months for zooplankton, to 5 months for cephalopods, 6 months for crabs and shrimp, 1 year for fish, 17 years for seals and 50 years for whales (calculated from the inverse of the $\mathrm{P} / \mathrm{B}$ ratios in Table 8.1, Christensen, 1995; Trites et al., 1999). Upwelling systems generally have shorter turnover times than shelves, reefs and estuaries (Christensen and Pauly, 1993). Longer residence times reflect greater accumulations of energy. Turnover times for aquatic primary production are extremely short compared with terrestrial systems (Ricklefs and Miller, 2000).

\section{Food Webs and Consumption in the Bering Sea}

A considerable amount of research currently is being focused on the eastern Bering Sea ecosystem, due largely to the decline of Steller sea lions (1977 to present) and their listing by the USA in 1997 as an endangered species (Alverson, 1992; Trites and Larkin, 1996; Loughlin, 1998). The cause of the population decline is not yet known, but may be related to a decline in prey abundance caused by fisheries or by natural changes in the ecosystem (Anon., 1993). Food web analysis and estimates of prey consumption are essential pieces of information needed to resolve this issue.

\section{Bering Sea food web dynamics}

Stomach contents and biomass estimates of fish, invertebrates, birds and mammals were collected by the then Soviet Union during the 1950s, and by the US National Marine Fisheries Service since the 1970s. Food webs constructed for the 1950s and 1980s (before and after the Steller sea lion decline started) suggest that the linkages between species were the same in each era (Fig. 8.2), but that dramatic changes occurred in the biomass of each group and in the amount of energy passing from one group to another (Trites et al., 1999). The mass balance ecosystem models constructed by Trites et al. (1999) suggest that most of the top predators (Trophic level IV) declined from the 1950s to the 1980s, along with a significant number of mid-trophic level species (i.e. crabs, shrimp and forage fishes such as herring and sandlance Trophic level III). Species that increased dramatically during this period (Fig. 8.4) included walleye pollock (level III) and large flatfish (level IV). Pollock appear to have contributed over $50 \%$ of the energy transferred at the mid-trophic levels during the 1980s compared with only $10 \%$ in the 1950 s. In contrast, pelagic fishes contributed nearly $50 \%$ of the total Bering Sea energy flow in the 1950s.

Stomach contents of Steller sea lions in the Gulf of Alaska suggest changes in their diet that are consistent with stock assessments and model predictions (Table 8.2). During the 1950s, Steller sea lion stomach samples contained mostly pelagic fishes (herring and sandlance), some gadids (pollock and cod) and no flatfish. From the 1960s to the 1990s, however, the dietary concentration of pelagic fishes fell, while gadids and flatfish became more prevalent (Table 8.2).

Attempts to simulate the effects of commercial fishing on the Bering Sea ecosystem failed to explain the change in ecosystem dynamics between the two eras (Trites et al., 1999). Fishing could not explain the decline of forage fish species (most of which were never fished), nor could it explain the $60 \%$ increase in large flatfish or the $400 \%$ increase in pollock. Food web interactions could not account for the magnitude of changes that occurred in the eastern Bering Sea. Instead, it appears that the survival of a suite of species was favoured over another by a combination of natural environmental changes in water temperatures and ocean currents. This is commonly referred to as a regime shift (Francis and Hare, 1994; Anderson et al., 1997; Beamish et al., 2000; Benson and Trites, 2002) 


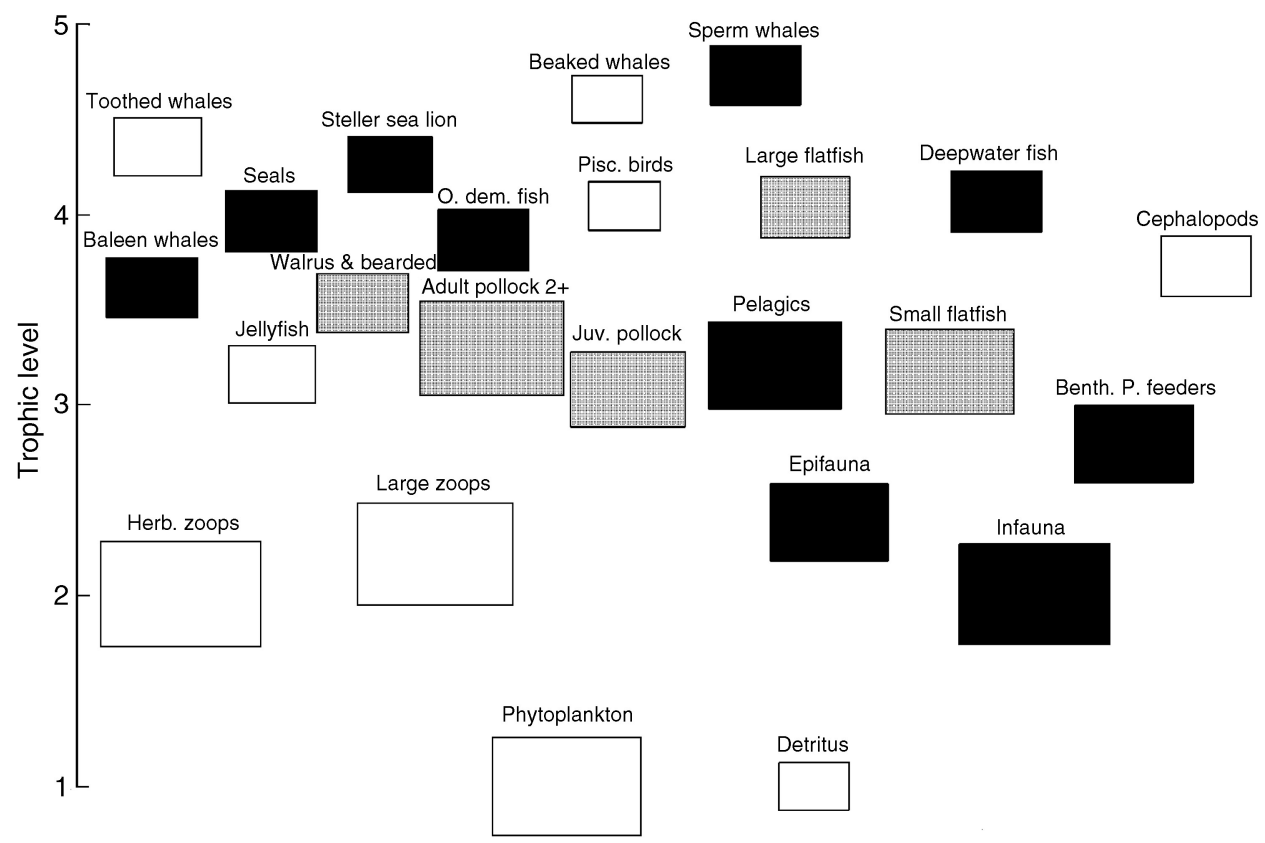

Fig. 8.4. Estimated trophic levels and relative biomass of species in the eastern Bering Sea during the 1980s. Black boxes indicate groups that had lower abundance in the 1980 s relative to the 1950 s, and shaded boxes show species that had higher abundance in the 1980s relative to the 1950s. Major flows of energy between the boxes are shown in Fig. 8.2 (from Trites et al., 1999).

Table 8.2. Changes in the proportion (1970s-1980s) or probability (1990s) of major prey types occurring in diets of Steller sea lions in the Gulf of Alaska (\%). Note that the sum of the percentages do not add up to $100 \%$.

\begin{tabular}{lccc}
\hline Period & Gadids & Flatfish & Pelagics \\
\hline $1950-1960$ s & Few & None & Mostly \\
$1976-1978$ & 32 & 0 & 61 \\
$1985-1986$ & 60 & 5 & 20 \\
$1990-1993$ & 85 & 13 & 18 \\
\hline
\end{tabular}

Source: from Merrick et al. (1997).

and suggests that the Bering Sea can exist in at least two alternative stable states that support suites of species at alternatively high and low population levels (Trites et al., 1999). Ecosystem indices from the models suggest that the Bering Sea was more 'mature' (sensu Odum, 1971) in the 1950s than in the 1980s, but is overall relatively resilient and resistant to perturbations (Trites et al., 1999).

Pollock and/or Atka mackerel (a hexagramid related to lingcod) currently dominate the diets of Steller sea lions in the declining populations that border the Bering Sea. This is in sharp contrast to the diets of growing sea lion populations in southeast Alaska and British Columbia that contain a more diverse array of prey (i.e. salmon, rockfish, forage fish, gadids and flatfish). Dietary diversity correlates with the rates of sea lion population change (Merrick et al., 1997), and suggests that the recovery of Steller sea lions is linked to consuming a more diverse range of species with higher fat (energy) contents than they currently are obtaining.

Recent field observations of foraging Steller sea lions suggest that they might choose preferentially herring over pollock (Thomas and Thorne, 2001). This is consistent with predictions of the junk-food hypothesis, which proposes that Steller sea lions have declined because they have been consuming too much pollock, which contain fewer calories, and not enough of the fattier, highenergy fishes (Alverson, 1992; Rosen and Trites, 2000b). 


\section{Estimating energy requirements}

Understanding how a change in diet could affect Steller sea lions comes from laboratory analysis of sea lions (digestive efficiencies and metabolism) and their prey (caloric and nutritional value). For example, bomb calorimetry analysis shows that herring (6-11 kJ g-1) has more energy per unit mass than do salmon $\left(5-9 \mathrm{~kJ} \mathrm{~g}^{-1}\right)$, pollock $(3-5 \mathrm{~kJ}$ $\mathrm{g}^{-1}$ ) or squid (4-6 $\mathrm{kJ} \mathrm{g}^{-1}$ ) (from data compiled by Winship and Trites, 2003). Feeding trials with captive Steller sea lions show that digestive efficiency $(90-95 \%$ of gross energy intake) increases with prey energy density, while heat increment of feeding $(10-20 \%$ of gross energy intake) decreases with increasing prey energy density (Rosen and Trites, 1997, 1999, 2000a). Digestive efficiency is the proportion of usable energy within a prey, and heat increment of feeding is the proportion of energy that is burnt during the mechanical and biochemical processes of digesting a prey item. Thus Steller sea lions can digest prey with higher fat content more easily than they can digest leaner prey. It also turns out that Steller sea lions have to burn more of the energy contained within larger prey to digest them than they do from smaller meal sizes (Rosen and Trites, 1997). Thus a Steller sea lion would have to eat an average of $56 \%$ more pollock than herring to obtain an equivalent amount of energy because pollock are bigger prey, contain fewer calories and require more energy to digest than do herring (Rosen and Trites, 2000b).

Estimating the amount of prey that Steller sea lions require can be determined by incorporating estimates of diet composition, digestive efficiencies, heat increments of feeding, activity budgets, body growth, basal metabolism and population size into bio-energetics models (Winship and Trites, 2003; Winship et al., 2002). They indicate that Steller sea lions in southeast Alaska require more food in winter and spring than they do during summer and autumn ( $45-60 \%$ more due primarily to seasonal changes in the energy density of the diet), and that the average sea lion requires about $17 \mathrm{~kg}$ of prey day ${ }^{-1}$, or $6000 \mathrm{~kg}$ year $^{-1}$. Within different regions of Alaska, per capita food requirements differ by as much as $24 \%$, depending upon the relative amounts of energy-poor prey (gadids) versus energy-rich prey (e.g. forage fish and salmon) that Steller sea lions consume (Fig. 8.5; Winship and Trites, 2003).

In 1998, the biomass of pollock and cod in Alaska was estimated at 11.57 million $\mathrm{t}(8.98$ million $\mathrm{t}$ pollock, 2.59 million $\mathrm{t}$ cod), with an annual natural mortality of 3.56 million $t$ (2.68 million t pollock, 0.88 million $\mathrm{t}$ cod), and a total commercial catch of 1.52 million $t$ (1.25 million $t$ pollock, 0.27 million $t$ cod) (see Winship and Trites, 2003). Total annual gadid consumption by Steller sea lions for all regions of Alaska was 0.18 million $t$ (Winship and Trites, 2003). Thus, consumption of gadids by Steller sea lions represented about $2 \%$ of the stock size, or $5 \%$ of natural mortality or $12 \%$ of commercial landing. Gadid consumption by Steller sea lions appears to be small relative to total gadid natural mortality and stock size, which is consistent with conclusions drawn by Livingston (1993).

Differences in the quality of prey available to Steller sea lions have consequences on the individual, and ultimately the population. One strategy an animal can invoke when faced with an energy shortage is to reduce the amount of prey they require by reducing their energy expenditures. Captive experiments have shown that Steller sea lions can reduce their metabolism by an average of $31 \%$ when food is withheld from them, which is typical of a fasting response (Rosen and Trites, 2002). However, sea lions do not appear to reduce their metabolism when fed smaller meals, despite losing body mass (Rosen and Trites, 2002). Instead, they exhibit a hunger response, which might lead them to increase their foraging effort in the wild. However, increased foraging effort has an increased energetic cost, as well as an increased risk of exposure to predation by sharks or killer whales.

Recently weaned young are the segment of the population most likely to incur the greatest cost of reduced caloric intake. Energetically, a 1-year-old female must consume 


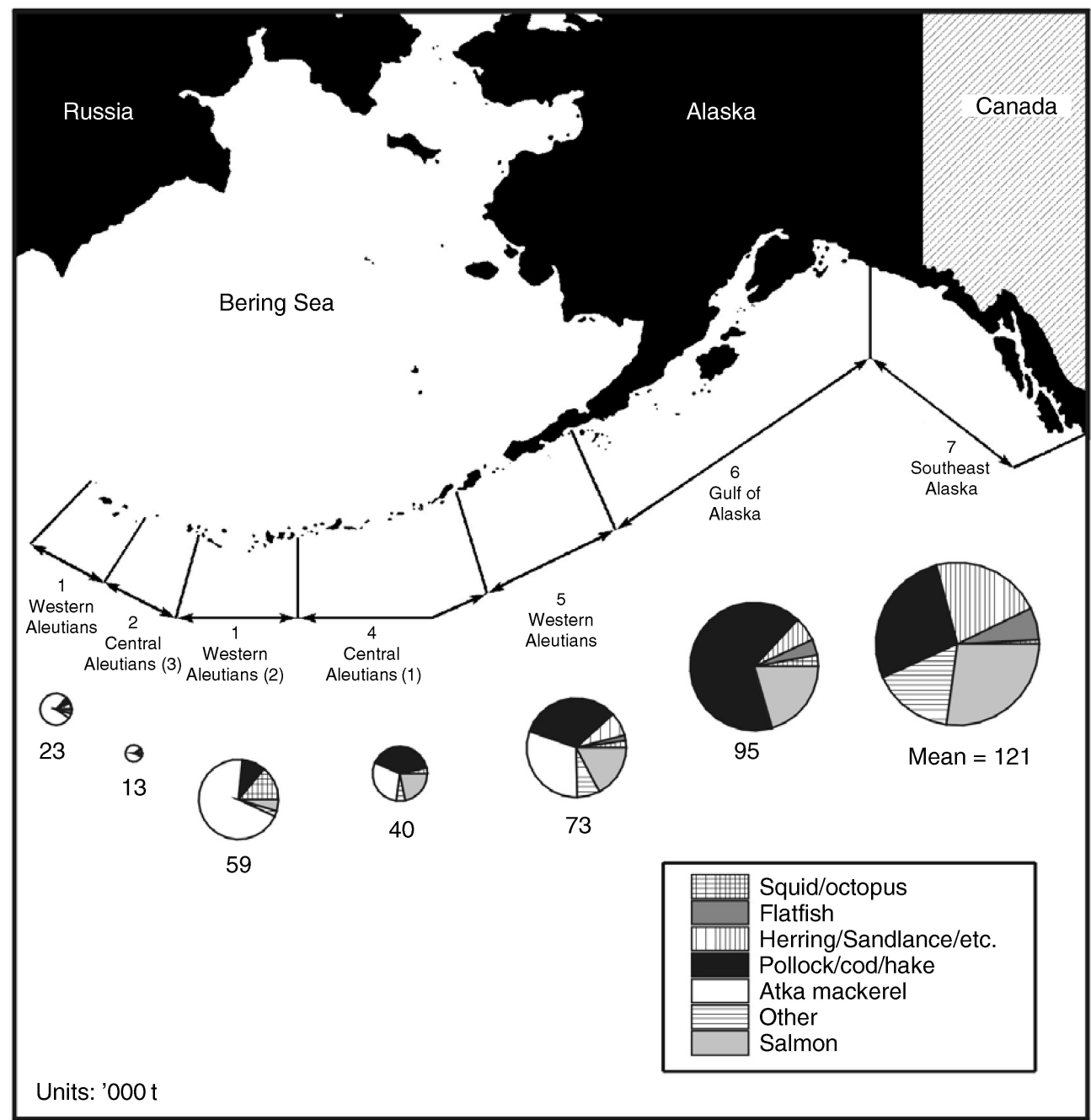

Fig. 8.5. Estimated annual food biomass requirements (thousands of t) for Steller sea lions in 1998 in seven study areas of Alaska, assuming that the summer diet was consumed all year long. Pie charts represent the proportions of diet biomass represented by each prey species category. Diameters of the pie charts are proportional to their respective mean food requirement estimates. Food requirements were calculated assuming digestive efficiency and the heat increment of feeding for maintenance varied with prey energetic density (from Winship and Trites, 2003).

about twice the relative quantity of prey compared with a mature female $(13 \%$ of her body weight per day eating a mixed diet, compared with $6 \%$ for a mature female; Winship et al., 2002). This same yearling female would require $9 \%$ of her body mass per day if she ate only small schooling fish, or $17 \%$ if she ate only gadids (Winship et al., 2002). These energy requirements could well be twice these values (i.e. $18-34 \%$ of body mass per feeding trip) considering that Steller sea lions do not eat every day, but typically fast for a day between their 1- or 2-day feeding trips (Trites and Porter, 2002). 


\section{Synthesis}

Combining the individual energy requirements with information about the changes that occurred in the Bering Sea food web suggests that the population decline of Steller sea lions in Alaska was probably related to the inability of young animals to acquire sufficient energy from the low-quality prey available to them. There is no indication of there being a shortage of low quality prey. However, the energetic modelling and captive feeding studies suggest it may not be physically possible for young Steller sea lions to consume enough low-energy prey to meet their daily energetic needs. Consuming fewer calories can stunt growth and cause reproductive failure (i.e. abortions) - symptoms that have been observed in Alaska over the time that Steller sea lions have declined (Calkins et al., 1998; Pitcher et al., 1998). A lower nutritional plane may also increase the susceptibility of sea lions to disease, and increase their risk of being killed by predators - a factor that may account for the apparent high mortality of juvenile sea lions (York, 1994). Mathematical modelling suggests that killer whales could have been a significant contributing factor in the decline of Steller sea lions, and may now be preventing the population from recovering (Barrett-Lennard et al., 1995).

\section{Conclusions}

The Bering Sea case study is an example of the importance of constructing food webs and estimating the energy requirements of marine organisms to understand ecosystem dynamics. This can only be achieved through a combination of fieldwork, captive studies and mathematical models - all of which are essential tools for the responsible management of fisheries and ecosystems. Food webs and energetic modelling shed light on the consequences of removing or adding organisms, and on the role that humans play in shaping the dynamics of marine ecosystems. More importantly, they are essential techniques for recognizing what our marine ecosystems once were, what they are currently and what they might be in the future.

\section{References}

Alverson, D.L. (1992) A review of commercial fisheries and the Steller sea lion (Eumetopias jubatus): the conflict arena. Reviews in Aquatic Sciences 6, 203-256.

Anderson, P.J., Blackburn, J.E. and Johnson, B.A. (1997) Declines of forage species in the Gulf of Alaska, 1972-1995, as an indicator of regime shift. In: Forage Fishes in Marine Ecosystems. Alaska Sea Grant, University of Alaska, Fairbanks, pp. 531-543.

Anon. (1993) Is it food? Addressing marine mammal and sea bird declines. Alaska Sea Grant Report 93-01. University of Alaska Fairbanks.

Baird, D., McGlade, J.M. and Ulanowicz, R.E. (1991) The comparative ecology of six marine ecosystems. Philosophical Transactions of the Royal Society of London 333, 15-29.

Barrett-Lennard, L.G., Heise, K., Saulitis, E., Ellis, G. and Matkin, C. (1995) The impact of killer whale predation on Steller sea lion populations in British Columbia and Alaska. University of British Columbia, B.C. Unpublished Report.

Beamish, R.J., McFarlane, G.A. and King, J.R. (2000) Fisheries climatology: understanding decadal scale processes that naturally regulate British Columbia fish populations. In: Parsons, T. and Harrison, P. (eds) Fisheries Oceanography: a Science for the New Millennium. Blackwell Science, Oxford, pp. 94-145.

Benson, A.J. and Trites, A.W. (2002) A review of the effects of regime shifts on the production domains in the eastern North Pacific Ocean. Fish and Fisheries 3, 95-113.

Briand, F. (1983) Environmental control of food web structure. Ecology 64, 253-263.

Briand, F. and Cohen, J.E. (1987) Environmental correlates of food chain length. Science 238, 956-960.

Burns, T.P. (1989) Lindeman's contradiction and the trophic structure of ecosystems. Ecology 70, 1355-1362.

Calkins, D.G., Becker, E.F. and Pitcher, K.W. (1998) Reduced body size of female Steller sea lions from a declining population in the Gulf of Alaska. Marine Mammal Science 14, 232-244. 
Christensen, V. (1995) A model of trophic interactions in the North Sea in 1981, the year of the stomach. Dana 11, 1-28.

Christensen, V. (1996) Managing fisheries involving predator and prey species. Reviews in Fish Biology and Fisheries 6, 417-442.

Christensen, V. (1998) Fishery-induced changes in a marine ecosystem: insight from models of the Gulf of Thailand. Journal of Fish Biology 53, 128-142.

Christensen, V. and Pauly, D. (1992) ECOPATH II a software for balancing steady-state ecosystem models and calculating network characteristics. Ecological Modelling 61, 169-185.

Christensen, V. and Pauly, D. (1993) Flow characteristics of aquatic ecosystems. In: Christensen, V. and Pauly, D. (eds) Trophic Models of Aquatic Ecosystems. 26th ICLARM Conference Proceedings, pp. 338-352.

Cohen, J.E. (1977) Ratio of prey to predators in community food webs. Nature 270, 165-167.

Cohen, J.E. (1978) Food Webs and Niche Space. Princeton University Press, Princeton, New Jersey.

Cohen, J.E. (1993) Concluding remarks. In: Kawanabe, H., Cohen, J.E. and Iwasaki, K. (eds) Mutualism and Community Organization. Oxford University Press, Oxford, pp. 412-415.

Cohen, J.E., Briand, F. and Newman, C.M. (1990) Community Food Webs: Data and Theory. Springer Verlag, New York.

Cottrell, P.E. and Trites, A.W. (2002) Classifying prey hard part structures recovered from fecal remains of captive Steller sea lions (Eumetopias jubatus). Marine Mammal Science 18, 525-539.

Croxall, J.P., Ricketts, C. and Prince, P.A. (1984) Impact of seabirds on marine resources, especially krill, of South Georgia waters. In: Whittow, G.C. and Rahn, H. (eds) Seabird Energetics. Plenum Publishing, New York, pp. 285-318.

Elton, C. (1927) Animal Ecology. Sidgwick and Jackson, London.

Francis, R.C. and Hare, S.R. (1994) Decadal-scale regime shifts in the large marine ecosystems of the North-east Pacific. Fisheries Oceanography 3, 279-291.

Grahl-Nielsen, O. and Mjaavatten, O. (1991) Dietary influence of fatty acid composition of blubber fat of seals as determined by biopsy: a multivariate approach. Marine Biology 110, 59-64.

Grosholz, E.D., Ruiz, G.M., Dean, C.A., Shirley, K.A., Maron, J.L. and Connors, P.G. (2000) The impacts of a non-indigenous marine predator in a California bay. Ecology 81, 1206-1224.
Guinet, C., Cherel, Y., Ridoux, V. and Jouventin, P. (1996) Consumption of marine resources by seabirds and seals in Crozet and Kerguelen waters: changes in relation to consumer biomass, 1962-85. Antarctic Science 8, 22-30.

Hacquebord, L. (1999) The hunting of the Greenland right whale in Svalbard, its interaction with climate and its impact on the marine ecosystem. Polar Research 18, 375-382.

Hall, S.J. and Raffaelli, D.G. (1993) Food webs: theory and reality. Advances in Ecological Research 24, 187-237.

Hall, S.J. and Raffaelli, D.G. (1996) Food web patterns: what do we really know? In: Kawanabe, H., Cohen, J.E. and Iwasaki, K. (eds) Mutualism and Community Organization. Oxford University Press, Oxford, pp. 395-417.

Hardy, A.C. (1924) The herring in relation to its animate environment. Part 1 . The food and feeding habits of the herring with special reference to the east coast of England. Fisheries Investigation Series II, 7, 1-53.

Hutchinson, G.E. (1959) Homage to Santa Rosalia, or why are there so many kinds of animals? American Naturalist 93, 145-159.

Huxham, M., Raffaelli, D.G. and Pike, A.W. (1995) Parasites and food web patterns. Journal of Animal Ecology 64, 168-176.

Innes, S., Lavigne, D.M., Earle, W.M. and Kovacs, K.M. (1987) Feeding rates of seals and whales. Journal of Animal Ecology 56, 115-130.

Iverson, S.J., Arnould, J.P.Y. and Boyd, I.L. (1997) Milk fatty acid signatures indicate both major and minor shifts in the diet of lactating Antarctic fur seals. Canadian Journal of Zoology 754, 188-197.

Jackson, J.B.C. et al. (2001) Historical overfishing and the recent collapse of coastal ecosystems. Science 293, 629-638.

Jarre, A., Palomares, M.L.D., Soriano, M.L., Sambilay, V.C.J. and Pauly, D. (1991) Some new analytical and comparative methods for estimating the food consumption of fish. ICES Marine Science Symposium 193, 99-108.

Jenkins, B., Kitching, R.L. and Pimm, S.L. (1992) Productivity, disturbance, and food web structure at a local spatial scale in experimental container habitats. Oikos 65, 249-255.

Jørgensen, S.E. (1998) A Pattern of Ecosystem Theories. Kluwer, Dordrecht, The Netherlands.

Kaelher, S., Pakhomov, E.A. and McQuaid, C.D. (2000) Trophic structure of marine food web at the Prince Edward Islands (Southern Ocean) determined by $\delta^{13} \mathrm{C}$ and $\delta^{15} \mathrm{~N}$ analysis. Marine Ecology Progress Series 208, 13-20.

Kelly, J.F. (2000) Stable isotopes of carbon and nitrogen in the study of avian and mammalian 
trophic ecology. Canadian Journal of Zoology 78 $1-27$.

Kendeigh, S.C., Lolnik, V.R. and Gavrilov, V.M. (1977) Avian energetics. In: Pinowski, J. and Kendeigh, S.C. (eds) Granivorous Birds in Ecosystems. Cambridge University Press, Cambridge, pp. 127-204.

Kirkman, S.P., Wilson, W., Klages, N.T.W., Bester, M.N. and Isalsen, K. (2000) Diet and estimated food consumption of Antarctic fur seals at Bouvetoya during summer. Polar Biology 23, 745-752.

Kirsch, P.E., Iverson, S.J., Bowen, W.D., Kerr, S.R. and Ackman, R.G. (1998) Dietary effects on the fatty acid signature of whole Atlantic cod (Gadus morhua). Canadian Journal of Fisheries and Aquatic Sciences 55, 1378-1386.

Kleiber, M. (1975) The Fire of Life: an Introduction to Animal Energetics. Robert E. Krieger, New York.

Klekowski, R.Z. and Duncan, A. (1975) Physiological approach to ecological energetics. In: Grodzinski, W., Klekowski, R.Z. and Duncan, A. (eds) Methods for Ecological Bioenergetics. IBP Handbook No. 24. Blackwell Scientific, Oxford.

Kozlovsky, D.G. (1968) A critical evaluation of the trophic level concept. 1. Ecological efficiencies. Ecology 49, 48-59.

Krebs, C.J. (1996) Ecology: the Experimental Analysis of Distribution and Abundance, 4th edn. AddisonWesley Educational, New York.

Lawler, S.P. and Morin, P.J. (1993) Food web architecture and population dynamics in laboratory microcosms of protists. American Naturalist 141, 675-686.

Lawton, J.H. (1989) Food webs. In: Cherrett, J.M. (ed.) Ecological Concepts: the Contribution of Ecology to an Understanding of the Natural World. Blackwell Scientific, Oxford, pp. 43-78.

Lawton, J.H. and Warren, P.H. (1988) Static and dynamic explanations for patterns in food webs. TREE 3, 242-245.

Lindeman, R. (1942) The trophic-dynamic aspect of ecology. Ecology 23, 399-418.

Livingston, P.A. (1993) Importance of predation by groundfish, marine mammals and birds on walleye pollock Theragra chalcogramma and Pacific herring Clupea pallasi in the eastern Bering Sea. Marine Ecology Progress Series 102, 205-215.

Loughlin, T.R. (1998) The Steller sea lion: a declining species. Biosphere Conservation 1, 91-98.

Mann, K.H. (1978) Estimating the food consumption of fish in nature. In: Gerking, S.D. (ed.) Ecology of Freshwater Fish Production. Blackwell Scientific, Oxford, pp. 250-273.
Martens, B. (1987) Connectance in linear and Volterra systems. Ecological Modelling 35, 157-163.

Martinez, N.D. (1991) Artifacts or attributes? Effects of resolution on the Little Rock Lake food web. Ecological Monographs 61, 367-392.

McConnaughey, T. and McRoy, P. (1976) Food-web structure and the fraction of carbon isotopes in the Bering Sea. In: Science in Alaska, 1976. Proceedings of the 27th Alaska Science Conference, Fairbanks, Alaska, 4-7 August 1976. Alaska Division of the American Association for the Advancement of Science, Fairbanks, pp. 293-316.

Merrick, R.L., Chumbley, M.K. and Byrd, G.V. (1997) Diet diversity of Steller sea lions (Eumetopias jubatus) and their population decline in Alaska: a potential relationship. Canadian Journal of Fisheries and Aquatic Sciences 54, 1342-1348.

Odum, E.P. (1971) Fundamentals of Ecology, 2nd edn. Saunders, Philadelphia.

Paine, R.T. (1980) Food webs: linkage, interaction strength and community infrastructure. Journal of Animal Ecology 49, 667-685.

Paine, R.T. (1988) Food webs: road maps of interactions or grist for theoretical development? Ecology 69, 1648-1654.

Paine, R.T. (1994) Marine Rocky Shores and Community Ecology: an Experimentalist's Perspective. Ecology Institute, Oldendorf.

Palomares, M.L. and Pauly, D. (1998) Predicting food consumption of fish populations as functions of mortality, food type, morphometrics, temperature and salinity. Marine Freshwater Research 49, 447-453.

Paul, A.J., Paul, J.M. and Smith, R.L. (1993) The seasonal changes in somatic energy content of Gulf of Alaska yellowfin sole, Pleuronectes asper. Journal of Fish Biology 43, 131-138.

Paul, A.J., Paul, J.M. and Smith, R.L. (1998) Seasonal changes in whole-body energy content and estimated consumption rates of age 0 walleye pollock from Prince William Sound, Alaska. Estuarine, Coastal and Shelf Science 47, 251-279.

Pauly, D. (1986) A simple method for estimating the food consumption of fish populations from growth data and food conversion experiments. Fishery Bulletin 84, 827-840.

Pauly, D. (1989) Food consumption by tropical and temperate fish populations: some generalizations. Journal of Fish Biology 35 (Supplement A), 11-20.

Pauly, D. and Christensen, V. (1995) Primary production required to sustain global fisheries. Nature 376, 279-279. 
Pauly, D., Trites, A.W., Capuli, E. and Christensen, V. (1998) Diet composition and trophic levels of marine mammals. Journal of Marine Science 55, 467-481.

Pimm, S.L. (1982) Food Webs. Chapman and Hall, London.

Pimm, S.L. (1991) The Balance of Nature? University of Chicago Press, Chicago, Illinois.

Pimm, S.L. and Kitching, R.L. (1987) The determinants of food chain lengths. Oikos 50, 302-307.

Pimm, S.L. and Lawton, J.H. (1977) Number of trophic levels in ecological communities. Nature 268, 329-331.

Pitcher, K.W., Calkins, D.G. and Pendleton, G.W. (1998) Reproductive performance of female Steller sea lions: an energetics based reproductive strategy? Canadian Journal of Zoology 76, 2075-2083.

Polis, G.A. (1991) Complex trophic interactions in deserts: an empirical critique of food-web theory. American Naturalist 138, 123-155.

Raffaelli, D. (2000) Trends in research on shallow water food webs. Journal of Experimental Marine Biology and Ecology 250, 223-232.

Ricklefs, R.E. and Miller, G.L. (2000) Ecology, 4 th edn. Freeman, New York.

Rosen, D.A.S. and Trites, A.W. (1997) Heat increment of feeding in Steller sea lions, Eumetopias jubatus. Comparative Biochemistry and Physiology 118A, 877-881.

Rosen, D.A.S. and Trites, A.W. (1999) Metabolic effects of low-energy diet on Steller sea lions, Eumetopias jubatus. Physiological and Biochemical Zoology 72, 723-731.

Rosen, D.A.S. and Trites, A.W. (2000a) Digestive efficiency and dry matter digestibility of Steller sea lions fed herring, pollock, squid and salmon. Canadian Journal of Zoology 78, 234-239.

Rosen, D.A.S. and Trites, A.W. (2000b) Pollock and the decline of Steller sea lions: testing the junk-food hypothesis. Canadian Journal of Zoology 78, 1243-1258.

Rosen, D.A.S. and Trites, A.W. (2002) Changes in metabolism in response to fasting and food restriction in the Steller sea lion (Eumetopias jubatus). Comparative Biochemistry and Physiology 132, 389-399.

Santos, M.B., Clarke, M.R. and Pierce, G.J. (2001) Assessing the importance of cephalopods in the diets of marine mammals and other top predators: problems and solutions. Fisheries Research 52, 121-139.

Schoener, T.W. (1989) Food webs from the small to the large. Ecology 70, 1559-1589.

Slobodkin, L.B. (1960) Ecological energy relationships at the population level. American Naturalist 94, 213-236.
Stenson, G.B., Hammill, M.O. and Lawson, J.W. (1997) Predation by harp seals in Atlantic Canada: preliminary consumption estimates for Arctic cod, capelin and Atlantic cod. Journal of Northwest Atlantic Fishery Science 22, 137-154.

Summerhayes, V.S. and Elton, C.S. (1923) Contributions to the ecology of Spitzbergen and Bear Island. Journal of Ecology 11, 214-286.

Thomas, G.L. and Thorne, R.E. (2001) Night-time predation by Steller sea lions. Nature 411, 1013-1013.

Tollit, D.J., Steward, M.J., Thompson, P., Pierce, G.J., Santos, M.B. and Hughes, S. (1997) Species and size differences in the digestion of otoliths and beaks: implications for estimates of pinniped diet composition. Canadian Journal of Fisheries and Aquatic Sciences 54, 105-119.

Trites, A.W. and Larkin, P.A. (1996) Changes in the abundance of Steller sea lions (Eumetopias jubatus) in Alaska from 1956 to 1992: How many were there? Aquatic Mammals 22, 153-166.

Trites, A.W. and Porter, B.T. (2002) Attendance patterns of Steller sea lions (Eumetopias jubatus) and their young during winter. Journal of Zoology (London) 256, 547-556.

Trites, A.W., Christensen, V. and Pauly, D. (1997) Competition between fisheries and marine mammals for prey and primary production in the Pacific Ocean. Journal of Northwest Atlantic Fishery Science 22, 173-187.

Trites, A.W., Livingston, P.A., Mackinson, S., Vasconcellos, M.C., Springer, A.M. and Pauly, D. (1999) Ecosystem change and the decline of marine mammals in the Eastern Bering Sea: testing the ecosystem shift and commercial whaling hypotheses. Fisheries Centre Research Reports 7(1).

Wada, E., Mizutani, H. and Minagawa, M. (1991) The use of stable isotopes for food web analysis. Critical Reviews in Food Science and Nutrition 30, 363-371.

Winberg, G.G. (1956) Rate of metabolism and food requirements of fishes. Fisheries Research Board of Canada Translation Series No. 194.

Winemiller, K.O. (1990) Spatial and temporal variation in tropical fish trophic net-works. Ecological Monographs 60, 331-367.

Winship, A. and Trites, A.W. (2003) Prey consumption by Steller sea lions in Alaska: how much do they require? Fishery Bulletin, in press.

Winship, A., Trites, A.W. and Rosen, D.A.S. (2002) A bioenergetics model for estimating the food requirements of Steller sea lions (Eumetopias jubatus) in Alaska. Marine Ecology Progress Series 229, 291-312. 
Wooten, J.T. (1994) Predicting direct and indirect effects: an integrated approach using experiments and path analysis. Ecology 75, 151-165.

Yodzis, P. (1998) Local trophodynamics and the interaction of marine mammals and fisheries in the Benguela ecosystem. Journal of Animal Ecology 67, 635-658.

York, A.E. (1994) The population dynamics of northern sea lions, 1975-1985. Marine Mammal Science 10, 38-51. 